\title{
Landscape values as a basis for subregional development
}

Landscape's soul lurks in man, who looks at it.

|- - - |

\section{Magdalena Opania}

\begin{abstract}
The article concerns the landscape of the tourist triangle of Kazimierz Dolny-Nałęczów-Puławy which became the basis for the a plan of regional development and cooperation. The purpose of the research presented in the article was to indicate the landscape's economic and social values based on selected documents, important from the point of view of landscape management, and to compare them with the subregion's strategic planning documents.

The methodology was based on the classic approach, used in the fields of spatial planning, urban planning and landscape architecture. In order to describe the problem and properly characteristize the examples selected to study individual cases, materials and documents related to the research problem were examined, including the final document of the European Landscape Convention and the Tourism Development Plan for the subregion covering the tourist triangle Kazimierz Dolny-Nałęczów-Puławy for 2012-2014 with a view to the year 2020. Field studies and own in situ observations were also carried out, supplementing the information in order to provide complete documentation of the selected cases.

Functional-spatial links within the subregion, along with local values resulting from valuable cultural, historical or natural phenomena and the need to transform the existing urban tissue, provide a chance to adapt the surrounding space to the new conditions. Hence, the author believes that interdisciplinarity is an integral aspect of the search for new possibilities of spatial solutions and the overall development of science. An interdisciplinary approach can be understood as a specific economic and strategic outlook of a region, supplemented by the reception of the landscape as an object of artistic action and contemplation so as to create a harmonious spatial-functional unit.
\end{abstract}

\section{Preface}

The author believes considerations concerning the landscape are a result of the need to reach an awareness of the value of space which surrounds us, its continuous, permanent transience and disappearing. A reflection on this issue also draws attention to the problem of contemplation of that which surrounds us: space - something essential to man and, increasingly today, decaying. Space: often beautiful, full of meaning, inseparable from the human being. Space which is additionally in the course of continuous transformation resulting in the irreversible disappearance of certain values.

\section{Area of research}

The case study applies to selected municipalities located in the immediate vicinity of: Puławy, Nałęczów and Kazimierz Dolny. The area analyzed consists of 11 municipalities in the Lubelskie region: Rams, Janowiec, Kazimierz Dolny, Końskowola, Kurów, Markuszów, 
Nałęczów, Wąwolnica and Wojciechów, Puławy, Żyrzyn. In total, it occupies an area of 96,500 ha and is inhabited by about 72,900 people. This subregion is the most popular destination in the Lubelskie region among tourists. Its unique characteristics are Kazimierz Dolny which occupies fifth place in the country on the list of brand-name Polish cities (after such urban centres as Cracow, Gdańsk, Warsaw and Wrocław) and the Nałęczów resort which reached third place in the ranking of the most popular spas in in the country (after Kołobrzeg and Krynica). This area is attractive due to its numerous monuments as well as charming nature and picturesque landscapes.

\section{Fig.1. The Vistula in Puławy}

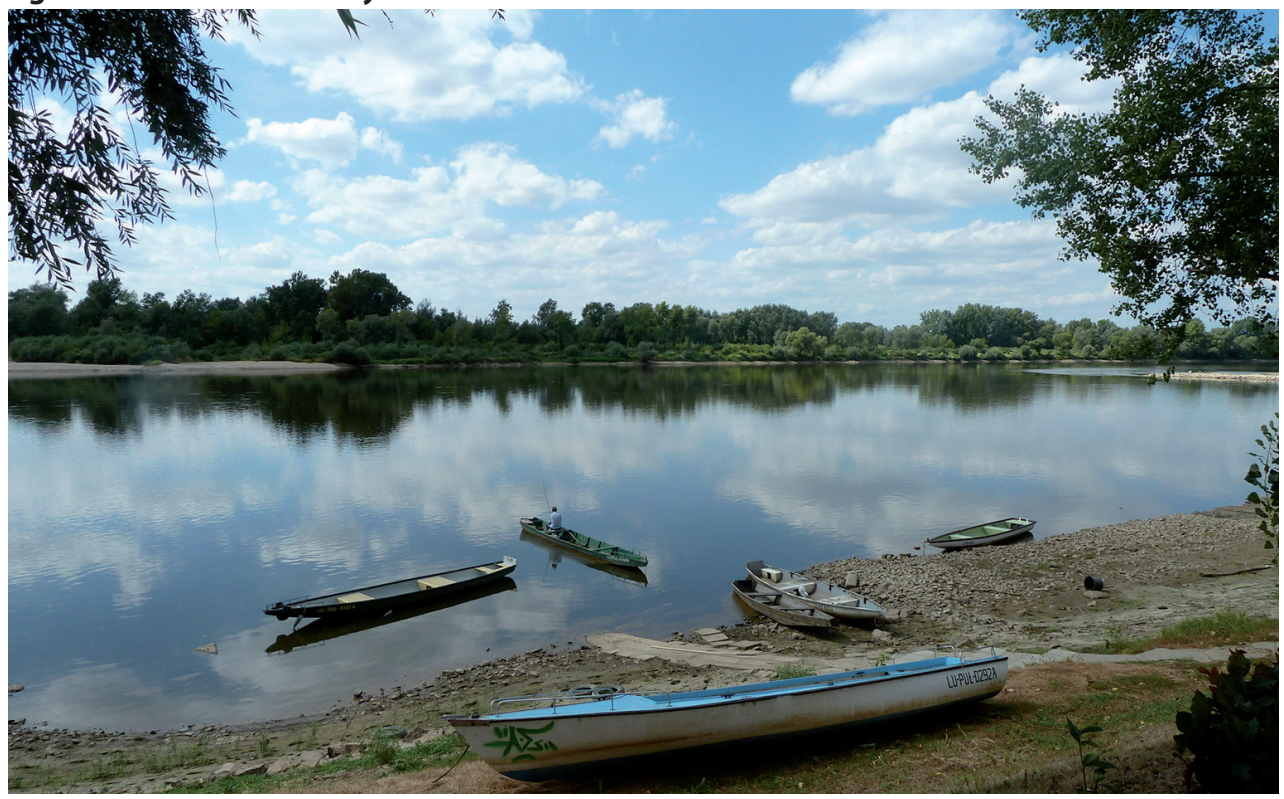

Source: author's own photography

In addition to the strong tourist resorts based on the area's rich history, the region is characterized by rich natural resources, cultural landscape and adjacent rural areas.

In the surveyed area, protected areas occupy 31,585 ha, which accounts for $33.0 \%$ of the surface area. Nature protection takes 98 different elements such as: nature parks, nature reserves, protected landscape areas, Natura 2000 areas and the Małopolska Breakthrough of the Vistula River Geopark 
Fig. 2. Hops plantations

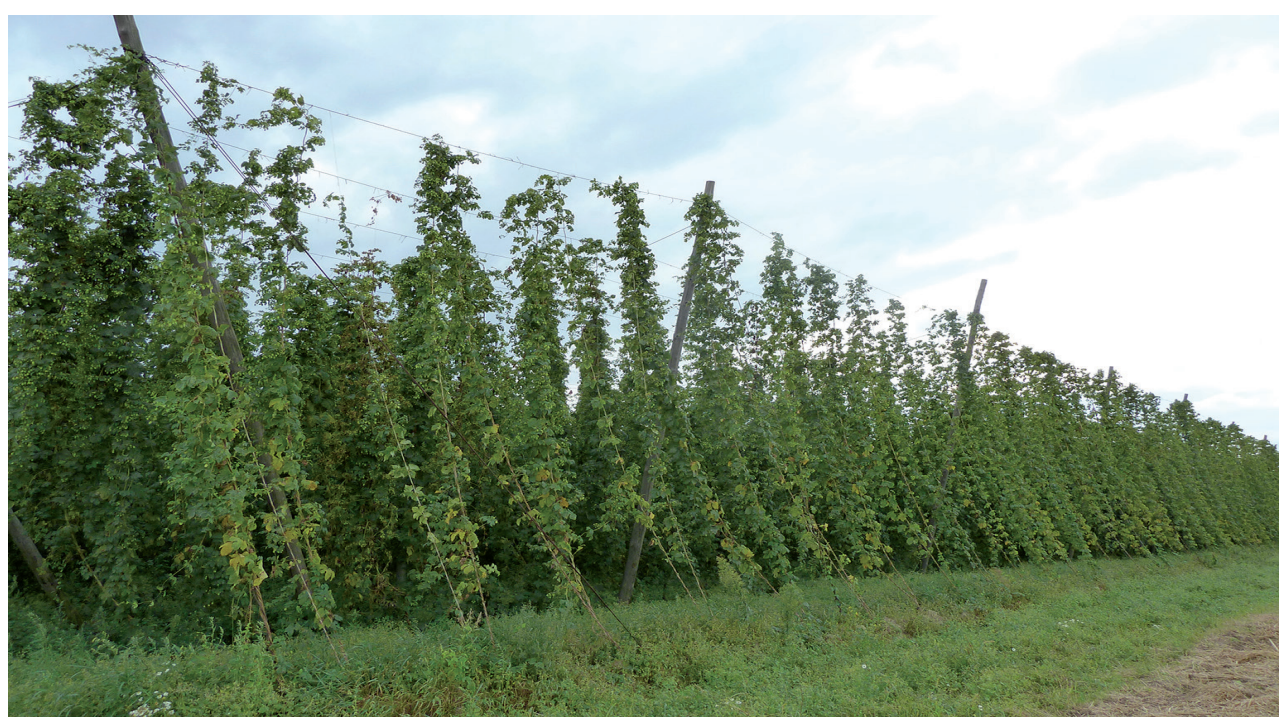

Source: author's own photography

\section{Fig. 3. Piskory Nature Reserve}

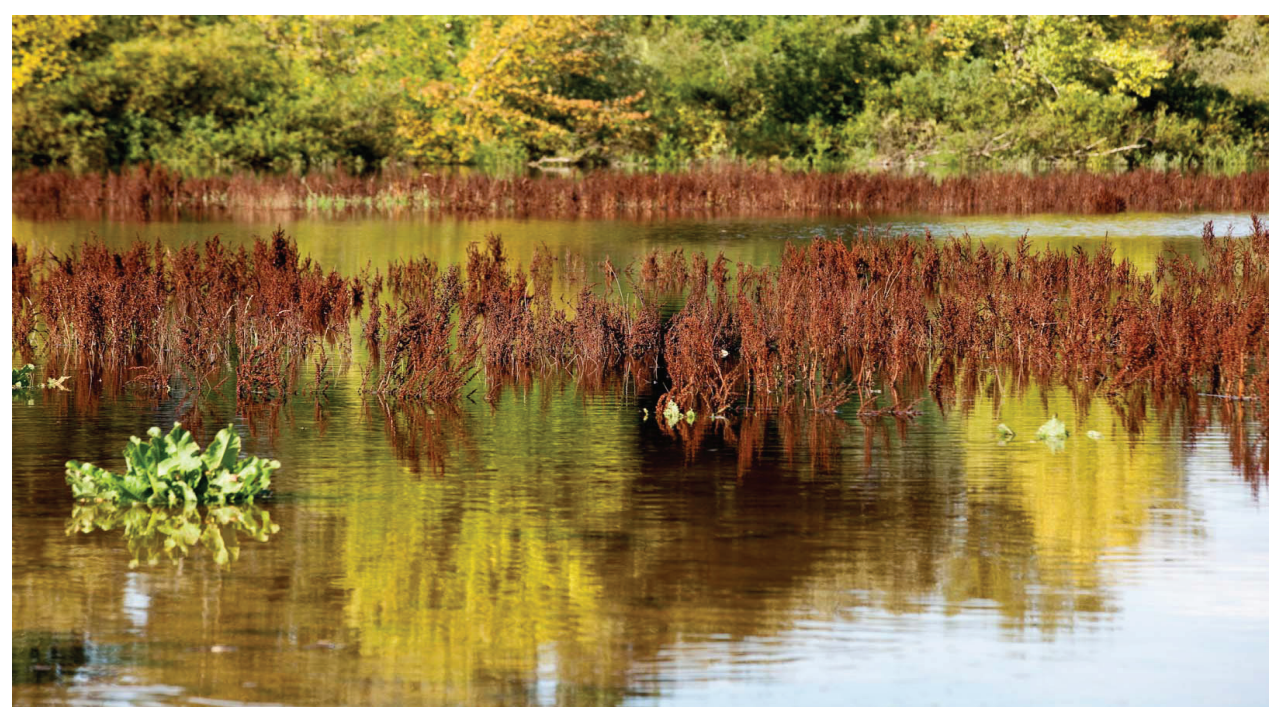

Source: http://www.krainarowerowa.pl, access: 15.05.2017 
Fig. 4. The value of the natural subregion covering the tourist triangle of Kazimierz DolnyNałęczów-Puławy

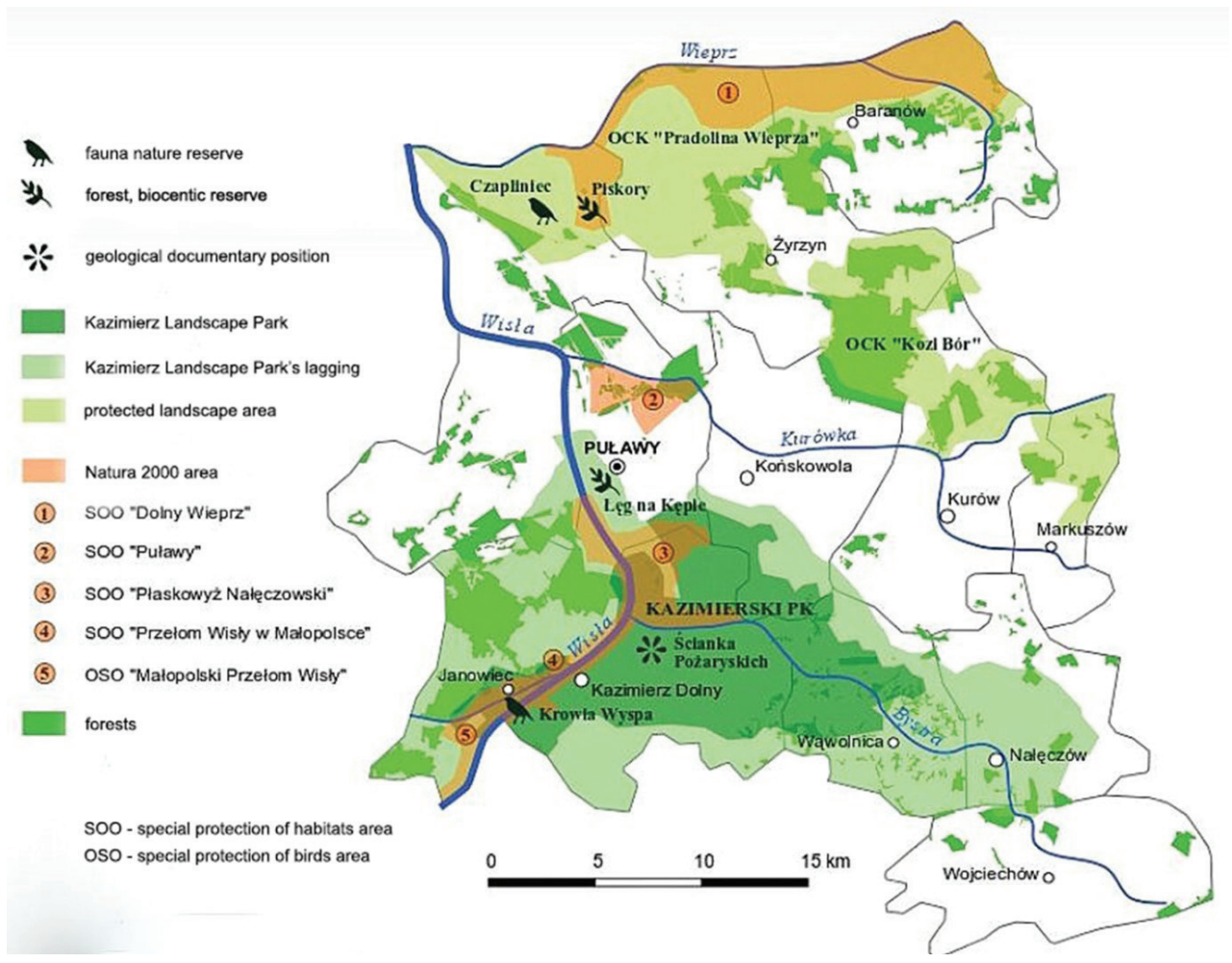

Source: Plan Rozwoju Turystyki dla subregionu obejmującego trójkq̨t turystyczny Kazimierz Dolny - Nałęczów Puławy na lata 2012-2014 z perspektywa do roku 2020 [Tourism Development Plan for the subregion covering the tourist triangle of Kazimierz Dolny-Nałęczów-Pulawy for 2012-2014 with a view to the year 2020]

\section{Theoretical basis of landscape reception}

The theoretical basis of landscape reception is essential to clarify the term of landscape itself, which will be used in the text and provide an explanation of how to interpret both terms. In the classical concept, landscape is defined as: physiognomy of the Earth's surface or a part of it, which is the synthesis of all the natural elements - mostly relief, climatic conditions, the plant and animal world - and human activities, in their mutual relations and interactions [Encyklopedia Powszechna 1984]. The definition shows that the problem of landscape focuses mainly on geography. Hence in geography we find a basis for the study of landscape and its breakdown into types, forms, varieties, etc.

Another important field of study is natural science, including biology and ecology. Studies in these disciplines have developed the concept of a growing landscape - including the biological aspect of its formation. Meanwhile, the discipline of spatial planning, along 
with urban planning, involves landscaping, i.e. providing directions and guidelines for the transformation of the space and environment in which we live.

As mentioned above, the term "landscape" functions in a variety of scientific disciplines, including geography, biology, but also geochemistry and, of course, architecture, and - above all - spatial planning. There is also a wide margin of colloquial understanding of the term.

The term landschaft-scenery, was used in the German language for a very long time, since at least the 10th century, according to Schmithüsena, initially in the sense of an area (regio), and then also to determine the nature of this area, its „contents" [Richling, Solon 1993, 9]. The focus on geographical space dominates up to the 15th/16th century, i.e. to the flowering of Flemish painting. It was then that a new meaning of the term was introduced: the view presented by the painter.

The term "landscape," widespread in Britain since the 17th century, was used both in the sense of the territorial form of terrain as well as that of a viewed environment. A visualaesthetic approach to the term „landscape”, specific to English-speaking countries, resulted in the development of research on the beauty of the landscape. According to Naveh and Lieberman - and probably in accordance with the feelings of the author of this paper - the original was an aesthetic understanding of the word landscape [Naveh, Lieberman 1984].

However, in the colloquial dictionary meaning, French paysage translates to "landscape". It is defined as a part of the country which can be watched, i.e. the urban or Mediterranean landscape, or as an array of specific species of flora and fauna [Dictionnaire du français 1971, primordial]. It turns out, however, that in Poland the scientific rigor and related concepts concern the broadly understood basics of artistic design of greens and gardens, with a strong emphasis on the technical side of selection of plants. Meanwhile, the issue discussed in this paper is addressed in the field of spatial planning.

Tha author agrees with this line of thought. Based on her humble life and professional experience, she has come to the conviction that drawing is, and should be, an indispensable element of everyday life and work, . Starting even from indicative sketches - how and which way you are to get somewhere, through a nice cut of garment seen recently, to professional sketches showing current projects. Perhaps drawing is a complementary element making up for the deficiencies in skills of naming and celebrating, but nevertheless, it can extend the forms of mutual communication.

An integral part of an architect's language should be the language of sketches. And it seems that the moment when the skills are used to pursue a hobby is close to the ideal.

Not without significance are the European Landscape Convention entries explaining the concept of the landscape as an area, perceived by people, the character of which is the result of the action and interaction of natural and human factors. The document also refers to landscape's role by finding that it plays an important role in the public interest, in the fields of culture, ecology and social affairs. It is also identified as a resource to encourage economic activity and its protection, as well as show how economy and planning can contribute to the creation of jobs [European Landscape Convention 2000]. 
The definition itself is extremely concise but capacious, especially in terms of the substance of landscape formation mechanisms. However, what is particularly important, satisfying the expectations of landscape perception and appreciation is determined by human activities, knowledge and skills to carry out the processes that make up the landscape. In this sense, landscape, formerly confined to a view and the emotions associated with it, rises today to the rank of a space management facility (while retaining its earlier features) [cf. Wiśniewska $2012,48]$.

\section{Landscape as a subject of contemplation}

The paper's subject was inspired by the author's personal interests related to manual drawing and photography, which evolved in the direction of observation, documentation and sketchy analysis of the surrounding environment's beauty. Through taking holiday photographs involving works resulting from design and scientific research, we increasingly focus on landscape photography. Vacations at home and abroad allow us to prepare, in time, a rich collection of panoramas and views of the Polish and European cities visited.

However, as Susan Sontag writes, photographic vision requires continuous refreshment, new shocks, whether thematic or technical, that we constantly have the impression of going out and raping the normal way of seeing. Under the influence of frequent apparitions, the way you look adapts to the latest photos. The formalistic treatment of the approximation of plants, shells, leaves, trees felled by the passage of time, seaweed, driftwood on the beach, washed rocks, the wings of the pelican, billowed cypress roots and twisted hands of the workman has become a platitude of a purely photographic way of seeing the world. What once required a particularly keen perception, now everybody can see [Sontag 1992].

The approach to landscape consideration probably closest to the author's own is a visualaesthetic attitude with Flemish roots. The starting point is an assumption that perception of the landscape caused, or causes, that what is next to us, is not often seen. We are rather accustomed to praise views "from somewhere else", from a distant journey, or old images captured by the hand of an artist, not recognizing the transient beauty which actually continues today and envelops us. Because in the end it's the artists who shape tastes, providing "synthetic" beauty, while awareness of the surrounding environment's state affects its reception almost directly.

That's why landscapes from trips, next to drawn sketches, were interspersed with notes on the state of the environment and a record of the region's images' uniqueness. The author would like to, without prejudice to the rights of artists, pay attention to the surrounding space, the preserved yet impressive views, and the need for their preservation and persistence. 
Fig. 5. Piotr Petrovich Konchalovsky, Siena-fragment-1912, canvas, oil, $82 \times 100 \mathrm{~cm}$. Simple solid buildings, light and colors quickly bring to mind the Tuscan landscape

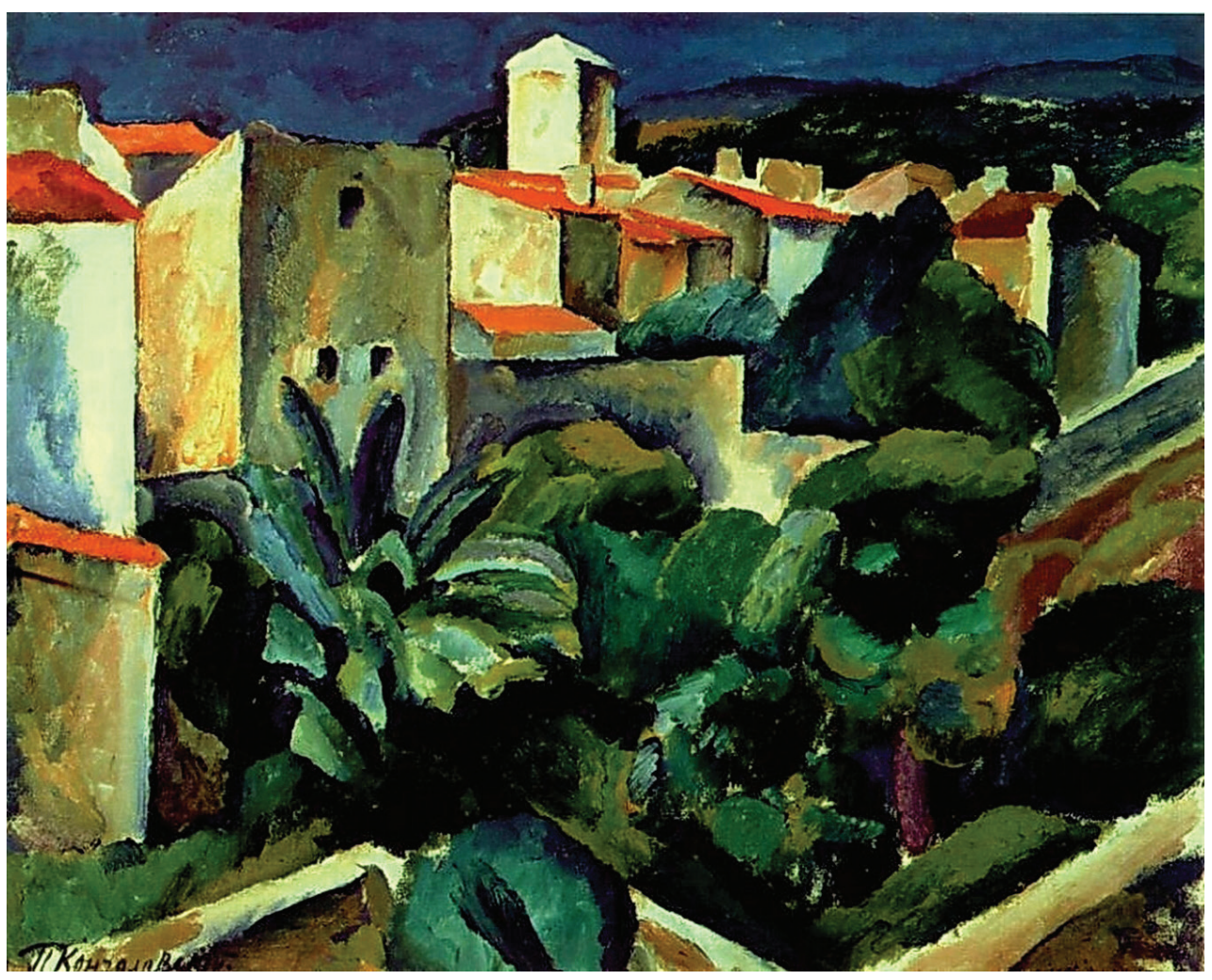

Source: Iljina T., 1989, Masterpieces of Russian painting in museums in the USSR, Aurora Publishing House, Leningrad

In the selection of beautiful landscapes, priority should be given to artists. Their sensitivity to the values of beauty and composition lets you rely on them. The ability to capture the most valuable shots, arrange lookouts, identify the best views, is the basis of their workshop. The rationale behind it has been explored in Janusz Bogdanowski's theoretical considerations. According to them particularly important is the place from which we observe the landscape. Different viewpoints provide different meanings for the same view. 
Table 1. Types of viewpoints by J. Bogdanowski

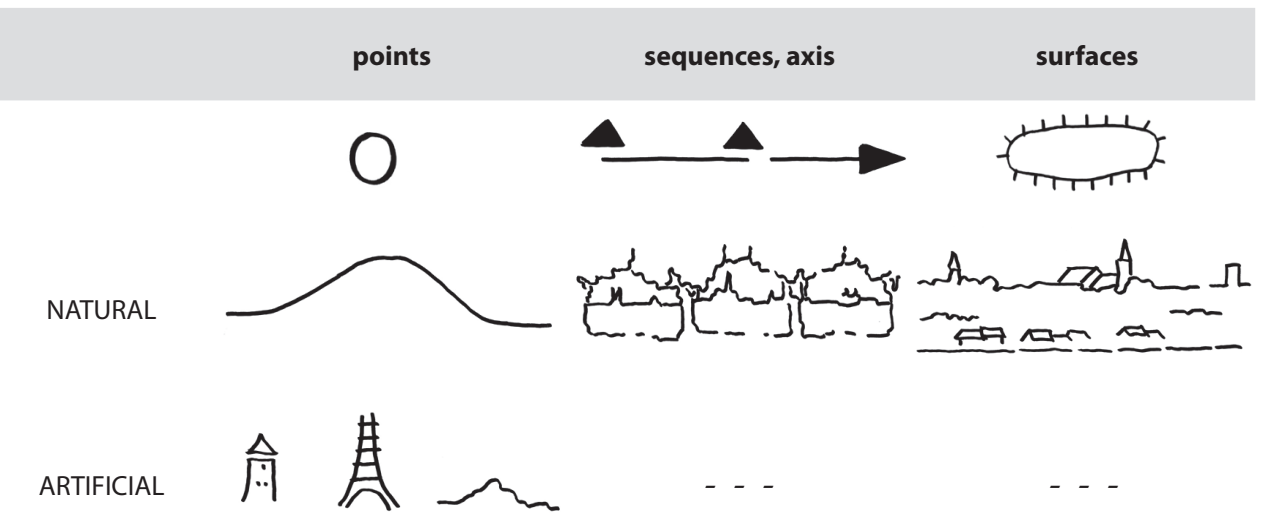

Source: Bogdanowski J., 1972, Konserwacja i kształtowanie w architekturze krajobrazu, Kraków

Table 2.The position of observation sites in relation to the city according to J. Bogdanowski

$\begin{array}{ccc}\text { relative height : } & \text { low point : } & \text { high point : } \\ \text { relative position to the city : } & \text { figurative shot } & \text { aerial view }\end{array}$

OUTER POINTS FAR:

watching a whole city or major pieces, lying generally in the landscape.

OUTER POINTS CLOSE: generally watching only part of the city lying in the immediate vicinity.
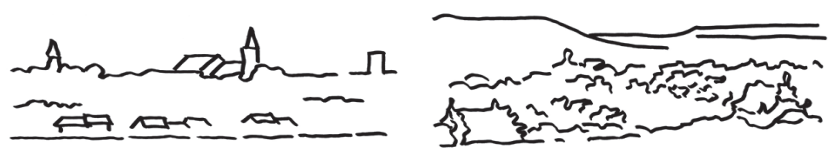

INNER POINTS:

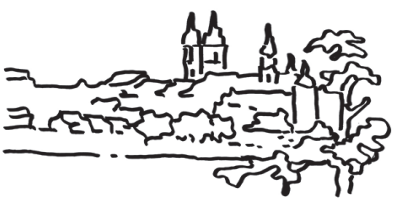


Fig. 6. Landscape of Kazimierz Dolny viewed from a natural hill inside the city

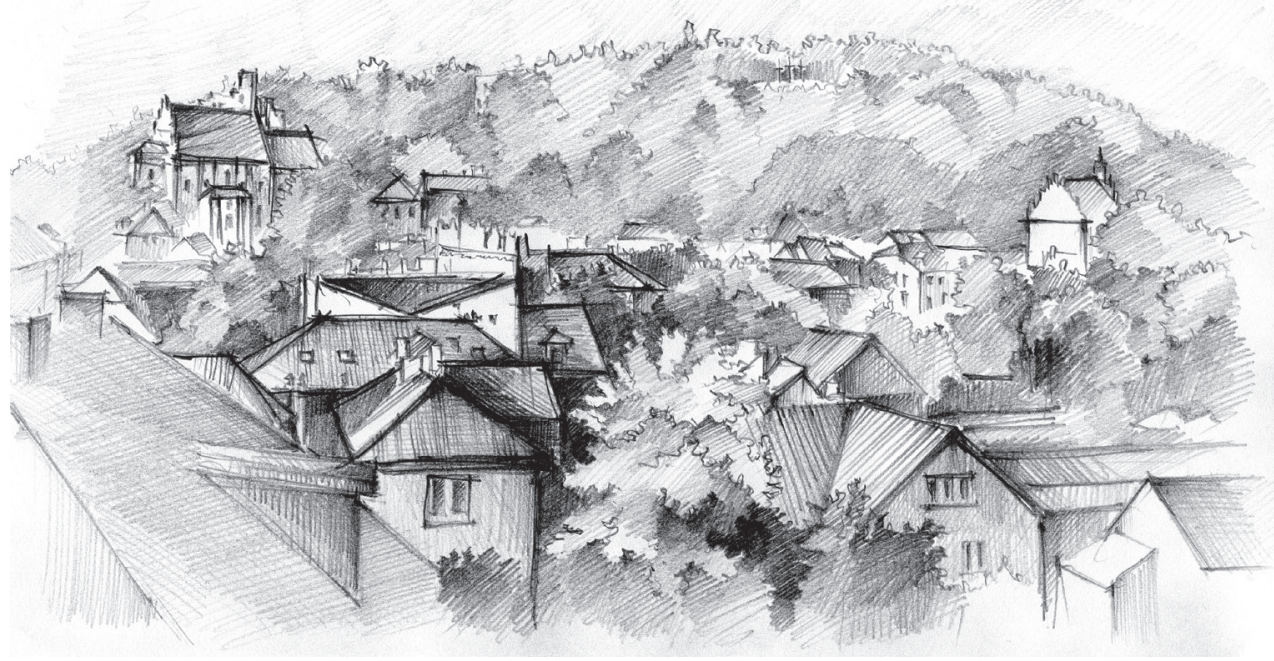

Source: author's own sketch

Fig. 7. Open countryside of the region

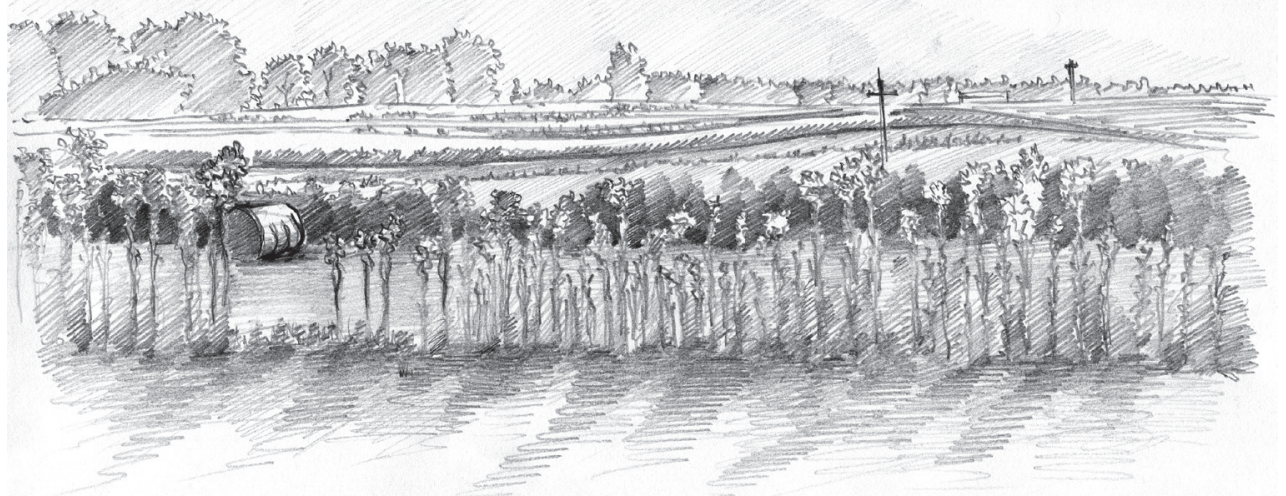

Source: author's own sketch 


\section{The use of landscaped qualities}

Such a utilitarian approach to the use of the landscape lies at the heart of the tourism development plan for the subregion covering the tourist triangle Kazimierz Dolny-NałęczówPuławy for 2012-2014 with a view to the year 2020. This plan is the result of a local association's assessment of functional-spatial and socio-economic links and their significance in the area. Those links complement the local values resulting from valuable cultural, historical or natural phenomena and the need to transform the existing urban tissue and adjust it to the new conditions. In this way the criteria are similar to the basics of building a functional area, a separate unit of spatial planning and development identified in the Polish National Spatial Development Concept 2030. Referring to the existing definition in planning law, a functional area is defined as "a compact spatial structure, consisting of functionally linked terrains, with common factors and anticipated uniform development goals" [Koncepcja przestrzennego zagospodarowania kraju 2030 (The concept of the Spatial Development for the country by 2030) 2012]. The plan was to strengthen the partnership for the development of the region in the framework of the project "Euro-opportunity for the Lublin region", for greater participation of actors other than a members of local government units. The main objectives were developing tourism in an area with unique potential, mainly in the field of active tourism, and making use of the values of the areas outside of the main known centers. In addition, the partnership was an opportunity to develop a model of interaction between different sectors: public, economic and social.

\section{Fig. 8. Cycling route map}

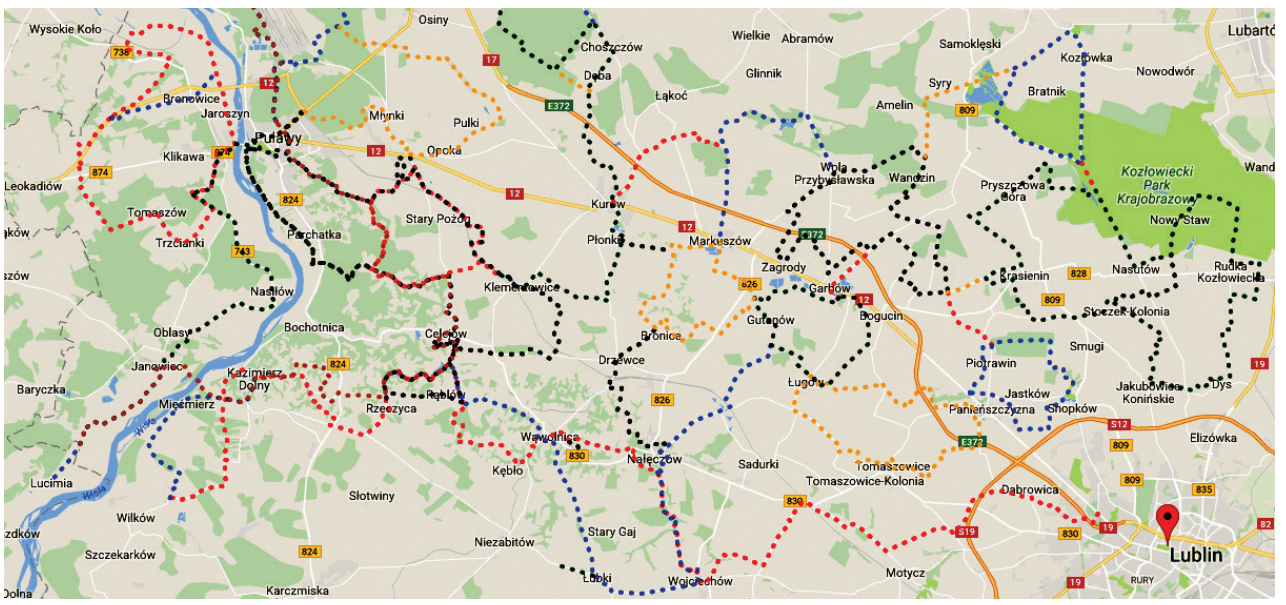

Source: http://www.krainarowerowa.pl, dostęp: 15.05.2017

The plan included 6 programmes and more than 20 tourism products targeted to promote active tourism and cognitive tourism based on the quality of the surrounding landscape. The programmes are: 
Fig. 9. A point on the route of the "rose" cycling route

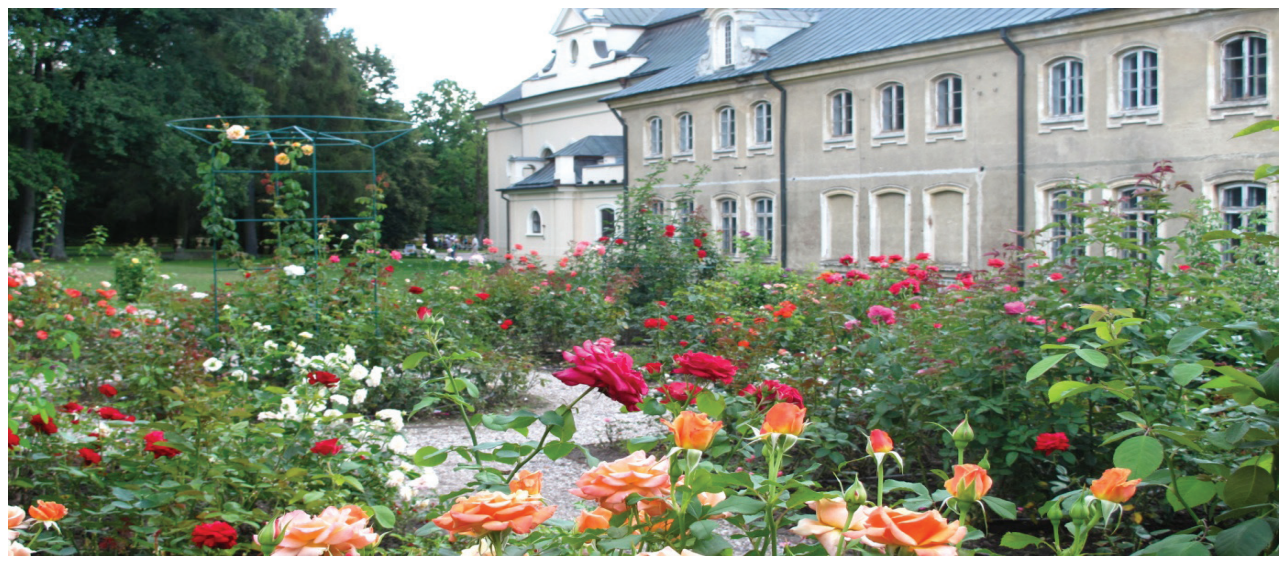

Source: author's own photography

1 - the touristic revival of the Wieprz Valley;

2 - restoring the glory of the Małopolska Breakthrough of the Vistula River;

3 - historical, cultural, religious heritage - as a tourist attraction;

4 - trails connecting terrains;

5 - specific unique tourist potentials of municipalities;

6 - strengthening of recognizable brands in the subregion based on new trends in tourism.

\section{Conclusion}

Functional-spatial links within the subregion, along with local values resulting from valuable cultural, historical or natural phenomena and the need to transform the existing urban tissue, provide a chance to adapt the surrounding space to the new conditions. A number of studies, documents and materials relating to the problem of the research, field studies and own observation made it possible to conclude that interdisciplinarity is an integral aspect of the search for new possibilities of spatial solutions and the overall development of science. An interdisciplinary approach can be understood as a specific economic and strategic outlook of a region, supplemented by the reception of the landscape as an object of artistic action and contemplation so as to create a harmonious spatial-functional unit.

This way of thinking was used while creating products of a travel network designed to maximize the impact on stimulating local entrepreneurship. It should be noted that these proposals require cooperation, and although 6 tasks are named, they repeatedly complement each other. An example of this might be a combination of two programs: 3 - historical, cultural, religious heritage - as a tourist attraction and 4 - trails connecting terrains in the form of the "rose" cycling route. 


\section{8 | LANDSCAPE VALUES AS A BASIS FOR SUBREGIONAL DEVELOPMENT \\ Magdalena Opania}

\section{Bibliography:}

Dictionnaire du français primordial, 1971, Micro Robert S.N.L., Paris.

Encyklopedia Powszechna, PWN, 1984,Warszawa.

Europejska Konwencja Krajobrazowa, 2000, Florencja.

Koncepcja Przestrzennego Zagospodarowania Kraju 2030, 2012, załącznik do uchwały nr 157 Rady Ministrów z dnia 25 września 2012r., Warszawa.

Naveh Z., Lieberman A., 1984, Landscape Ecology - Theory and Application, Springer Verlag, New York.

Plan Rozwoju Turystyki dla subregionu obejmujacego trójkąt turystyczny Kazimierz Dolny Nałęczów - Puławy na lata 2012-2014 z perspektywa do roku 2020.

Richling A. i Solon J., 1993, Ekologia krajobrazu, PWN, Warszawa.

Sontag S., 1992, O fotografii, [w:] 6/9 fotografia, nr 1(6),III.92.

Ustawa o planowaniu i zagospodarowaniu przestrzennym, z dnia 27 marca 2003 r.

Wielki Stownik Francusko-Polski, 1980, Wydawnictwo Wiedza Powszechna, Warszawa.

Wiśniewska W., 2012, Krajobraz miejski: odnowa i kreacja w procesie odnowy, Wydawnictwo Politechniki Łódzkiej, Łódź. 


\title{
Wartości krajobrazu jako podstawa rozwoju subregionalnego
}

\section{STRESZCZENIE}

Artykuł jest poświęcony krajobrazowi subregionu trójkąta turystycznego Kazimierz Dolny - Nałęczów - Puławy, który stał się podstawą do założeń rozwoju i współpracy ponadregionalnej.

Celem badań przedstawionych w artykule było wskazanie wartości ekonomicznych i społecznych krajobrazu w oparciu o wybrane, ważne z punktu widzenia zarządzania krajobrazem dokumenty oraz porównanie ich ze strategicznymi dokumentami planistycznymi subregionu.

Przyjęta metodologia pracy opierała się na klasycznym podejściu, stosowanym w pracach z dziedzin planowania przestrzennego, urbanistyki i architektury krajobrazu. W celu opisania problemu i przeprowadzenia właściwej charakterystyki przykładów wybranych do studium indywidualnych przypadków przeanalizowano materiały i dokumenty związane z problemem badawczym, takie jak dokument końcowy Europejskiej Konwencji Krajobrazowej oraz Plan Rozwoju Turystyki dla subregionu obejmującego trójkąt turystyczny Kazimierz Dolny - Nałęczów - Puławy na lata 2012-2014 z perspektywą do roku 2020. Zostały również przeprowadzone badania terenowe i obserwacje własne in situ stanowiące uzupełnienie informacji w celu pełnej dokumentacji wybranych przypadków.

Powiązania funkcjonalno-przestrzenne w badanym subregionie uzupełnione o wartości lokalne, tworzone przez wysokie walory kulturowe, historyczne czy przyrodnicze oraz konieczność przekształcania istniejącej tkanki urbanistycznej dają szanse dostosowywania otaczającej przestrzeni do nowych warunków.

Stąd w przekonaniu Autorki wydaje się, iż nieodłącznym aspektem poszukiwania nowych możliwości rozwiązań przestrzennych oraz ogólnego rozwoju nauki jest interdyscyplinarność. Konkretne spojrzenie ekonomiczno-strategiczne dotyczące danego regionu, uzupełnione przedstawionym odbiorem krajobrazu jako przedmiotu kontemplacji i działań artystycznych, mające tworzyć harmonijną przestrzenno-funkcjonalną całość.

\author{
$\overline{\text { Magdalena Opania }}$ \\ student of Architecture at Silesian University of Technology. \\ Member of Student's Organisation AntyRama, member of Polskie Towarzystwo Turystyczno-Krajobrazowe, \\ memeber of Stowarzyszenie Instruktorów i Trenerów Narciarstwa. \\ Connects passion for travels, active life with urban and architectural design. \\ Contact: \\ Wydział Architektury, Politechnika Śląska, ul. Akademicka 7, 44-100 Gliwice, \\ tel. +48-661-603-093, \\ e-mail:magda.opania@gmail.com
}

